\title{
CORPORATE GOVERNANCE REFORM: \\ INFLUENCE ON SHAREHOLDER WEALTH
}

\author{
Richard W. Pouder \\ R. Stephen Cantrell \\ Clemson University \\ Clemson, SC
}

\begin{abstract}
Many corporations have adopted governance practices advocated by shareholder activists. To date, the net effect of such practices is largely unknown. Both practitioners and academics agree that additional research is required to determine whether governance practices have actually improved corporate performance. This paper attempts to resolve some of the uncertainties surrounding changes in governance practice. We consider four governance practices widely advocated by shareholder activists and test whether their net and individual effects have an impact on shareholder returns following layoff announcements.
\end{abstract}

\section{Introduction}

Over the past two decades, shareholders have become an increasingly vocal and influential force in the governance reform movement. As advocates of governance reform, shareholder activists anticipate that certain changes in governance practice will better align their economic interests with those of management. The conceptual platform for the governance reform movement is agency theory. From this perspective, governance changes would be expected to make the board of directors more effective monitors of managements' strategies. As a consequence of improved monitoring, strategies ratified by the board should more closely reflect shareholder interests and thus increase shareholder wealth.

In a recent special issue on governance, Business Week reported that governance changes have been observed in most major corporations over the past two decades with further changes expected (Byrne, 1997). Four governance changes receiving much attention are: (1) substantially increasing the proportion of unaffiliated outside directors, (2) separating the positions of CEO and board chairperson, (3) increasing stock incentives offered to board members, and (4) increasing the proportion of common shares held by institutional investors. Although the proportion of firms separating their CEO and board chairperson has essentially remained constant (Baliga, Moyer, \& Rao, 1996), activists have successfully pressured corporations to adopt each of the other three changes sought. 
While significant changes in corporate governance have been adopted as a result of the shareholder activist movement, it is not known whether the net effect of these changes actually improves performance. As Business Week asks, "How much is good governance worth? These days, corporate chieftains, shareholder activists, and academics are hotly debating that question" (Byrne, 1997, p. 116). Much of this debate stems from inconsistent research findings concerning the performance implications of governance practices. These inconsistencies are made clear in a recent meta-analysis of board composition, leadership structure, and financial performance by Dalton, Daily, Ellstrand, \& Johnson (1998). Their results show little systematic support for relationships between governance elements and financial performance.

Most of the arguments noted above are from the point of view of investors and owners. Managers, however, have an interest in good governance as well. From their point of view, if good governance practices are employed, will owners and investors recognize that they are in place and put more faith in managers' decisions? The purpose of this research is to test empirically whether managerial decisions made under conditions of acceptable governance practice are more likely to increase shareholder wealth than managerial decisions that are not.

In this study we consider a strategic decision that is inherently controversial: layoffs. Layoffs can be part of a long-range repositioning or downsizing that has strategic merit and will likely result in improved investor wealth. Such is the case in several recent layoffs at Procter and Gamble that were part of a decision to exit certain markets, while repositioning in others. Layoffs can also be part of a myopic decision to improve short range operating income that likely decreases shareholder wealth, as evidenced in recent waves of layoffs made by Eastman Kodak. ${ }^{1}$ Assuming that the decision to lay off a portion of the workforce will likely be weighed for strategic value by the stock market, we ask the question: Are firms that employ good governance practices more likely to experience a positive market reaction to their layoff plans than firms that do not employ good governance practice? To answer this question, we organize the remainder of the paper as follows. First, we discuss governance problems perceived from an agency theory perspective. Second, we use the agency perspective to explain the relationship between governance practices and layoffs. Third, we give a brief account of research findings on governance elements, develop hypotheses, and describe our empirical approach. Finally, we present the results and conclude by discussing their implications and limitations.

\section{The Role of Governance}

\section{An Agency Theory Perspective}

The governance concerns of investors and owners follow from agency theory. Agency theory focuses on the relationship between principals and agents: that is, those who delegate work (principals) and those who perform work for the princi- 
pals (agents) (Jensen \& Meckling, 1976). Casting this relationship as a contract (Jensen \& Meckling, 1976), agency theorists examine the problems that can arise between different forms of principal-agent relationships. In the agency theory framework, shareholders in large corporations (principals) hire managers (agents) to initiate and implement important decisions (Fama \& Jensen, 1983). However, the risk preferences and interests of shareholders may differ from those of managers. Driven by self-interest, managers may choose strategies that increase their compensation over strategies that respond to shareholders' wishes to increase the market value of the firm (Fama \& Jensen, 1983). Shareholders will thus seek governance practices that monitor managers' decision making activities.

\section{An Agency View of Governance and Layoffs}

According to agency theory, the board of directors monitors and ratifies strategies formulated by management (Fama \& Jensen, 1983; Jensen \& Meckling, 1976). Although the board rarely formulates strategy (Harrison, 1987; Hoskisson, Johnson, \& Moesel, 1994), it reviews strategies to mitigate managerial inefficiencies (Zahra \& Pearce, 1989) that misalign strategies with shareholder interests. Earlier research findings suggest that the extent of board involvement and control in strategic issues varies substantially among firms (Johnson, Hoskisson, \& Hitt, 1993; Judge \& Zeithaml, 1992). More recent evidence from the specialized governance and academic literatures, suggests that, over the past decade, shareholder activists have influenced many boards to augment their involvement by evaluating a broader range of strategies (Clyde, 1997; Lear, 1997; Lear \& Yavitz, 1997; Lorsch, 1996; Witte, 1997), and in improving the quality of their evaluations (Dobrzynski, 1993b; Gordon, 1994).

Some earlier evidence suggests boards may not seriously consider layoff strategies or their consequences (Horton, 1991). Unlike strategies such as mergers and anti-takeover provisions, layoffs do not legally require board intervention and approval. In accordance with governance changes instigated by activists, we contend that boards have played a greater role in monitoring managements' layoff strategies over the past decade. Although limited, the business literature provides anecdotal support for this contention (e.g., Collins, 1993; Heenan, 1993; Morrissey, 1994; Queenan, 1996). Furthermore, layoffs are often part of an internal corporate restructuring or downsizing (Freeman \& Cameron, 1993). Over the past decade governance reform activists have successfully pressured boards to become more active monitors of internal corporate restructuring and re-engineering strategies (Nelson, 1995). For example, the boards of General Mills, IBM, Ford Motor Company and L.A. Gear were all active in internal restructuring that involved significant job cuts. Major shareholders such as CalPERS have also become increasingly concerned with "corporate responsibility" and discourage boards from supporting employment policies that seek short term gains ("Corporate Responsibility," 1996). 


\section{Governance Elements}

Given that boards are becoming more vigilant and better informed monitors of managements' layoff strategies, we next consider specific changes sought by shareholder activists in individual governance elements.

\section{Board Composition}

Shareholder activists maintain that boards should be comprised of a majority of outside directors. Boards dominated by inside director-managers are more likely to seek policies aligned with management rather than shareholder interests. This results in agency problems as discussed above. Activists also argue that even outside directors may be favorably biased toward management. As a consequence of the governance reform movement, the Securities Exchange Commission has established guidelines for defining outside directors in Regulation 14A, Item 6(b). Affiliations that negate outsider status are based on past employment in the corporation, relationship by blood or marriage, and certain business transactions conducted with the corporation.

It is also widely believed by the business press and academics that boards are more effective in protecting shareholder interests when there are greater proportions of unaffiliated directors (see Zahra \& Pearce, 1989 for discussion; McLaughlin, 1994; Mizruchi, 1983; Schellhardt, 1991). Empirical research findings show that higher proportions of outside directors are significantly associated with protecting shareholder interest in the following strategic contexts: removal of incompetent CEOs (Weisbach, 1988); stock market reaction to announcements of poison pills (Brickley, Coles, \& Terry, 1994); stock market reaction to acquisition announcements (Brickley \& James, 1987); and, boards sued for failing to meet their responsibilities to shareholders (Kesner \& Johnson, 1990). Other studies fail to show significant associations in the following settings: failed retail firms (Chaganti, Mahajan, \& Sharma, 1985); entrepreneurial firms (Daily \& Dalton, 1992); stock market reaction to antitakeover provisions (Sundaramurthy, Mahoney, \& Mahoney, 1997); and level of CEO power (Daily \& Johnson, 1997).

\section{Board Leadership}

Agency problems may develop when the chairperson also serves as CEO. Dual CEO/chairperson positions are likely to be viewed as more prominent and influential by board members. This confers an image of power that may hinder the board's ability to monitor independently (Beatty \& Zajac, 1994) and introduces a pro-management board orientation (Lorsch, 1989). Alternately, separation of chairperson and CEO promotes the interest of shareholders through independent evaluation of the CEO and management and by introducing issues that directly affect shareholders (Sundaramurthy \& Rechner, 1997). As in research on director independence, empirical findings that explore the link between dual chair- 
person/CEO are mixed (cf., Baliga, Moyer, \& Rao, 1996; Beatty \& Zajac, 1994; Chaganti, Mahajan, \& Sharma, 1985; Daily \& Dalton, 1997; Rechner \& Dalton, 1991).

\section{Director Stock Incentives}

Performance-based incentives for directors is another important governance element in the shareholder activist movement. Agency theorists argue that stock ownership by directors provides an incentive to improve their effectiveness in monitoring managers' decisions because they have a greater personal stake in the wealth effects of those decisions (Jensen \& Meckling, 1976). In line with this prediction, governance reformers have influenced corporations to increase director stock ownership as an attempt to better align shareholder and managerial interests (McLaughlin, 1994). Equity ownership encourages inside and outside directors to protect the interests of shareholders because these directors benefit from higher firm performance (Westphal \& Zajac, 1995). In addition, directors increase their voting rights in proportion to their equity ownership, thereby bringing their interests into even closer alignment with shareholders (Zald, 1969). Some empirical studies on equity ownership by directors find that such incentives act to increase the board's monitoring of management, resulting in the choice of strategies that increase shareholder wealth (e.g., Hoskisson, Johnson, \& Moesel, 1994; Mallette \& Fowler, 1992; Rediker \& Seth, 1995; Westphal \& Zajac, 1995). Other empirical research fails to support the views espoused by agency theory and shareholder activists (e.g. Byrd \& Hickman, 1992; Kosnik, 1987; Sundaramurthy et al., 1997).

\section{Stock Ownership by Institutional Investors}

Individual investors owning few shares exercise low control over potential agency problems because they have limited voting power and cannot economically obtain information about managements' activities. The consolidation of external ownership, mainly by institutional investors, has both increased voting power and facilitated cost-effective collection of information on board activities. Large shareholders are better able to pressure boards to ratify strategies that serve their interests. Unsurprisingly, as ownership of stock by institutions has grown from about 9\% in 1970 to over 50\% in 1996 (Chaganti \& Damanpour, 1991; Sundaramurthy \& Rechner, 1997), institutions have become a dominant force in the governance reform movement (Byrne, 1997; Pound, 1992).

Because institutional investors often hold a large number of shares, they cannot easily shift their investments to other companies; they therefore will seek a more active role in the choice of a firm's strategies (Changanti \& Damanpour, 1991; Davis \& Thompson, 1994). This suggests that when firms announcing a layoff have a high proportion of institutional ownership, there is a greater likelihood that their boards have considered shareholder interests in ratifying management's layoff strategy. Although there is some research and anecdotal 
evidence linking greater institutional ownership to improved monitoring, most research studies show insignificant findings (cf., Chaganti \& Damanpour, 1991; Dobrzynski, 1997a; Graves, 1988; Mallette \& Fowler, 1992; Sundaramurthy, 1996; Sundaramurthy et al., 1997).

\section{Governance Practice and Stock Market Response}

Is governance reform related to the choice of layoff strategies that improve performance? Activists would contend that layoff strategies in firms whose boards are involved and effective monitors of management are more likely to improve performance than layoff strategies in firms whose boards are not involved and effective monitors of management. To test this idea, we measure performance using abnormal returns associated with the stock market's reaction to a layoff announcement. In announced stock market events performance is measured by stock market anticipation of value rather than post hoc accounting data. (Lubatkin \& Shrieves, 1986). This implies that the stock market is aware of a firm's governance and its performance implications when the firm announces a layoff.

For the following reasons, we assume that stock returns associated with a layoff announcement would be expected to incorporate the future costs or benefits ascribed to a firm's governance practices. First, a central tenet of financial economics is that efficient markets capture all publicly available information (Fama, 1976). If investors consider a firm's governance practices in assessing its layoff announcement, then the abnormal returns associated with the layoff should be related to the firm's governance practices. Second, a steady stream of evidence from the business press, including regularly published rankings of firms' governance practices, tend to make governance practices and issues highly visible (Byrne, 1997; Heenan, 1993). Third, institutional shareholders are majority shareholders in many corporations. These shareholders have much at stake, making them highly visible to the stock market (Brickley, Lease, \& Smith, 1994). Finally, the following event studies show that the market can view, and is influenced by each governance element: board composition (Brickley, Coles, \& Terry, 1994; Hermalin \& Weisbach, 1988; Lubatkin, Chung, Rogers, \& Owers, 1989; Rosenstein \& Wyatt, 1990); director stock ownership (Brickley, Lease, \& Smith, 1988; McWilliams, 1990; Stulz, 1988); and dual versus separate CEO and chair positions (Sundaramurthy, et al., 1997).

The foregoing suggests that the stock market should perceive good governance practices in firms. Accordingly, layoff announcements in such firms would be valued higher than layoff announcements in firms that do not subscribe to good governance practices. From a managers' perspective, positive or negative stock market reactions to the firm's layoff strategy should signal that a good or poor governance practice is in place, respectively. This leads to the following hypothesis: 
Hypothesis 1: Corporate governance practices are significantly related to positive and negative changes in shareholder value following a layoff announcement.

Besides the overall effect of governance practices on shareholder value, managers would be interested to know the impact of individual governance elements on firm performance. As previously discussed, research findings in support of an agency theory approach to corporate governance are ambivalent. We therefore set up the following null hypotheses to test the effects of each governance element on performance:

Hypothesis 2: Announcement effects of board composition on shareholder value will be zero.

Hypothesis 3: Announcement effects of dual CEO and chairman positions versus separate $C E O$ and chairman positions on shareholder value will be zero.

Hypothesis 4: Announcement effects of director stock ownership on shareholder value will be zero.

Hypothesis 5: Announcement effects of institutional stock ownership on shareholder value will be zero.

\section{Method}

\section{Sample}

An event study methodology provides measures of abnormal stock market returns (see Brown \& Warner, 1985, for a comprehensive explanation of event study methodology). As a first step, we reviewed the Wall Street Journal Index for announcements of layoffs during the 1989-1993 time period. We eliminated announcements of layoffs in the auto, airline, and defense contractor industries. Layoffs in these industries tend to follow a regular and somewhat predictable pattern, which could dampen market reaction to the announcement (McWilliams \& Siegel, 1997). We also eliminated announcements of layoffs that may have been confounded by other significant events such as changes in key executives, plant closings, changes in dividend policy, announcements of mergers, and changes in earnings. We dropped firms that had filed for bankruptcy protection. In all, we eliminated 91 announcements from an original total of 222 announcements, resulting in a final sample size of 131 announcements for 102 firms. The Appendix lists firms in the sample and their corresponding layoff announcement dates. 


\section{Measures}

An event study uses the "market model," which proposes a relation between the return on a stock, over a given period of time, and the return on the market portfolio over the same time period (Brown \& Warner, 1985). This information and all other stock information used in our study was obtained from the Center for Research in Security Prices University of Chicago (CRSP) tapes. We estimated the market model using one trading year of daily returns (from 331 to 91 days before the announcement). The two-day time period of the announcement date and previous day $(\mathrm{t}-1, \mathrm{t}=0)$ showed the greatest cumulative abnormal returns (CARs). For this reason, and because short time periods are more likely to exclude confounding events than long windows (McWilliams \& Siegel, 1997), this two day period serves as the event window from which we compute our dependent variable.

This research tests if governance practice can accurately predict a positive or negative market return in response to a layoff announcement. The dependent variable is therefore dichotomous, coded as a " 1 " for positive CARs and " 0 " for negative CARs (no CAR had a value of zero).

Four independent variables used in the analysis are proportion of outside directors, separation of CEO and chairperson, proportion of common shares held by all directors, and proportion of common shares held by institutional investors. Information on the first three variables comes from proxy statements for the year prior to the layoff announcement. We define outside directors consistent with SEC Regulation 14A, Item 6(b). Shares held by institutional investors comes from the Value Line Investment Survey for the reporting date that most closely precedes the layoff announcement.

We include three control variables. The stock market reaction to a layoff announcement may be influenced by the size of the layoff (Worrell, Davidson, \& Sharma, 1991), which we measure as the percentage of the work force targeted for a layoff. We also suspect that the firm's size and profitability influence the market reaction to a layoff announcement. Larger and more profitable firms are more visible, and therefore likely to be subject to greater scrutiny. We use the firm's sales for the year before the layoff to measure size. To control for a firm's profitability, we use return on equity for the year prior to the layoff announcement.

\section{Statistical Model}

One of our interests is to see if overall governance practice can predict positive and negative abnormal returns. A second interest is to see if individual governance elements are significantly related to positive and negative abnormal returns. Because the dependent variable is dichotomous and our hypotheses require testing the signs of individual variables, we use logistic regression to analyze the data. A logistic regression model also has the following advantages: its regression coefficients are easy to interpret; it can compensate for the distorting effects of 
unequal proportions of dependent variables by allowing specification of the proportion of firms having positive and negative abnormal returns; it estimates the proportion of dependent variables correctly classified, and it can accommodate dichotomous independent variables (e.g., separate and dual CEO/chairperson).

\section{Results}

Table 1 presents means, standard deviations and intercorrelations. There are no excessively high correlations $(r>.70)$, indicating that multicollinearity is not likely to be a problem. Consistent with previous research, the average proportion of institutional ownership is $53.0 \%$ and $78.0 \%$ of CEOs also serve as chairperson of the board. The average percentage of employees that a firm expected to layoff was $6.5 \%$. The average percentage of outside directors on boards was $61.0 \%$ and directors held $3.0 \%$ of outstanding common shares.

\section{Table 1}

Means, Standard Deviations, and Intercorrelations of Variables

Variables

Mean S.D.

12

3

1. Cumulative Abnormal Returns

$$
(t=-1, t=0)
$$

$0.44 \quad 0.50$

2. CEO/Chairperson Separation

3. Proportion of Outside Directors

$\begin{array}{lll}0.78 & 0.42 \quad .06\end{array}$

4. Proportion of Institutional Ownership

5. Proportion of Shares Held by Directors ${ }^{a}$

$\begin{array}{llll}0.61 & 0.17 & .15 & .15\end{array}$

6. Percentage Layoff Announced

7. Return on Equity

8. Sales ${ }^{b}$

$0.53 \quad 0.16 \quad .27 * * .02 \quad .18 *$

$\begin{array}{llllll}75.73 & 221.00 & -.17 & -.19 * & -.37 * & -.11\end{array}$

$\begin{array}{lllllll}6.48 & 5.70 & -.01 & .03 & .08 & -.17 & .12\end{array}$

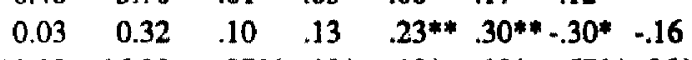

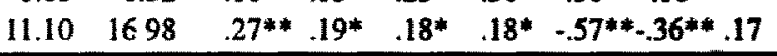

$N=131$

a Porportion of shares held by directors transformed to its natural logarithm.

b Expressed in millions of dollars, transformed to natural logarithm in the logistic regression.

${ }^{*} p<.05$

$* * p<.01$

Table 2 presents the proportion of negative and positive CARs, and the proportion of correctly classified CARs for the logistic regression model (adjusted for the probability of observed outcomes). The model correctly classifies $69.5 \%$ of the 131 abnormal returns associated with a layoff announcement $(67.6 \%$ of negative CARS and $71.9 \%$ of positive CARs are classified correctly, respectively). 
Table 2

Classification Results for Logistic Regression Modelab

\begin{tabular}{ccccc}
\hline $\begin{array}{c}\text { Observed Abnormal } \\
\text { Returns }\end{array}$ & $\begin{array}{c}\text { Predicted Negative } \\
\text { Abnormal Returns }\end{array}$ & $\begin{array}{c}\text { Predicted Positive } \\
\text { Abnormal Returns }\end{array}$ & Total \\
\hline \multirow{2}{*}{ Count } & Negative & 50 & 24 & 74 \\
& Positive & 16 & 41 & 57 \\
\hline \multirow{3}{*}{ Percent } & Negative & 67.6 & 32.4 & 100.0 \\
& Positive & 28.1 & 71.9 & 100.0 \\
\hline
\end{tabular}

a Percentage correctly classified $69.5 \%$

$b$ Adjusted for proportion of positive and negative abnormal returns (44.0\% and $56.0 \%$, respectively)

Table 3 reports the logistic regression analysis, which addresses the relationship between governance elements and change in shareholder value following a layoff announcement. As indicated by the value of chi-square, the model has a high goodness of fit $(p<.01)$, suggesting that corporate governance practices are significantly related to positive and negative changes in shareholder value following a layoff announcement as proposed in Hypothesis 1. Table 3 also reveals that institutional investor stock ownership is a significant, positive predictor of changes in market returns ( $p$ slightly greater than .01) following a layoff announcement. However, no other governance element is significantly related to market returns following a layoff announcement. Sales, used as a measure of firm size, is a highly significant and positive predictor of changes in shareholder value.

\section{Conclusion and Implications}

Academic and practitioner support for governance reform has grown steadily over the past two decades. Despite research and anecdotal evidence that some governance practices are associated with improved firm performance, an unanswered question is whether positive or negative performance effects can be predicted from attempts to improve governance. Our findings suggest that four governance practices collectively can accurately predict positive or negative abnormal stock returns for about $70 \%$ of the cases in this study. Whether the net effect of governance practices advocated by activists actually improves governance or is just perceived as protecting shareholder interests, the logistic regression shows that, overall, the market reaction is significantly related to governance practice. 
Table 3

Logistic Regression Analysis

Market Reaction to Layoff Announcements, Governance and Control Variables

\begin{tabular}{|c|c|c|c|c|}
\hline Variable & Coefficient & $\begin{array}{c}\text { Standard } \\
\text { Error }\end{array}$ & $\begin{array}{c}\text { Wald } \\
\text { Statistic } \\
\end{array}$ & $P$-value \\
\hline CEO/Chairperson Separation & -.0197 & .4873 & .0016 & .9678 \\
\hline Proportion of Outside Directors & .8375 & 1.2724 & .4332 & .5104 \\
\hline Proportion of Institutional Ownership & 3.5693 & 1.3874 & 6.6181 & .0101 \\
\hline Proportion of Shares Held by Directors ${ }^{a}$ & .0311 & .1234 & .0637 & .8007 \\
\hline Percentage Layoff Announced & .0537 & .0395 & 1.8501 & .1738 \\
\hline Return on Equity & .0812 & .7654 & .0113 & .9155 \\
\hline Sales ${ }^{a}$ & .4310 & .1694 & 6.4741 & .0109 \\
\hline Constant & -6.7218 & 2.0628 & 10.6179 & .0011 \\
\hline
\end{tabular}

$\mathrm{N}=131,-2 \log$ Likelihood $=158.871$, Chi Square $=20.571,7 \mathrm{df}, p=.0045$.

a Transformed to natural logarithm value.

The logistic regression also shows that the model's significance stems largely from the positive effect of institutional shareholdings on stock market reaction. This empirical finding supports expectations of agency theory and shareholder activists. However, none of the other three governance practices is significantly associated with market reaction to layoff announcements. This pattern of results suggests that the market perceives greater proportions of institutional investment to be most closely associated with good governance practice. At the same time, internal governance elements (i.e., greater proportions of outside directors, separation of CEO and chairperson, and higher levels of director stock ownership) appear to have little effect on determining whether the market reacts negatively or positively to layoff announcements. The following may explain this pattern of results. Institutional investors represent a large proportion of shareholder activists and own a majority of shares in most large corporations. Accordingly, when institutions own a greater proportion of shares in a corporation they may signal to the market a stronger likelihood that their influence will improve internal monitoring and choice of layoff strategies, regardless of whether recommended internal governance practices have been adopted. As Pfeffer (1981) suggests, the board may be symbolically signaling its governance role.

These results have several implications. First, there is overall support for the idea that firms having better governance tend to be better performers. Better governance can be largely attributed to concentration of ownership by institutional investors. Consequently, managers contemplating layoffs should look at the level of institutional shareholdings in their firms to help make more informed decisions concerning whether layoffs will increase or decrease shareholder value. Second, in the context of layoffs, it appears that other acceptable governance practices have less influence on performance than agency theory and activists 
would predict. This is consistent with research findings in other contexts and implies that multiple conceptual approaches are needed to better explain corporate governance (for example, see Daily et al., 1998).

These results should be interpreted with caution. Findings of insignificant performance effects associated with internal governance elements may indicate that the market does not perceive the board to play a key role in monitoring and ratifying layoff strategies. Future research in corporate governance needs to investigate the extent of board involvement in layoff strategies. Research methods in this area could include interviews and surveys targeted for directors and CEOs. Finally, the event study methodology implicitly assumes that the market can evaluate the full benefits of governance practices. A timely and useful follow-up to this study would test the long term implications of governance on layoffs using accounting-based performance measures.

\section{References}

Baliga, B. R., Moyer, R. C., \& Rao, R. S. (1996). CEO duality and firm performance: What's the fuss? Strategic Management Journal. 17, 1-43.

Beatty, R., \& Zajac, E. (1994). Managerial incentives, monitoring, and risk bearing: A study of executive compensation, ownership, and board structure in initial public offerings Administrative Science Ouarterly. 39, 313-335.

Brickley, J. A., \& James, C. M. (1987). The takeover market, corporate board composition, and ownership structure: The case of banking. Journal of Law and Economics, 30, 161-180.

Brickley, J. A., Coles, J. L., \& Terry, R. L. (1994). Outside directors and the adoption of poison pills. Journal of Financial Economics. 35, 371-390.

Brickley, J. A., Lease, R. C., \& Smith, C. W. (1988). Ownership structure and voting on antitakeover amendments. Journal of Corporate Finance, 1, 5-31.

Brown, S., \& Warner, J. (1985). Using daily stock returns: The case of event studies. Journal of Financial Economics. 14, 3-31.

Byrd, J. W., \& Hickman, J. A. (1992). Do outside directors monitor managers? Journal of Financial Economics, 32, 195-221.

Byrne, J. A., (1997, September 15). The CEO and the board. Business Week, 106-116.

Chaganti, R. S., Mahajan, V., \& Sharma, S. (1985). Corporate board size, composition and corporate failures in retailing industry. Journal of Management Studies. 22, 400417. 
Chaganti, R. S., \& Damanpour, F. (1991). Institutional ownership, capital structure, and firm performance. Strategic Management Journal $12,479-491$.

Clyde, P. (1997). Do institutional shareholders police management? Managerial and Decision Economics, 18, 1-10.

Collins, T. (1993, April 29). Stetson group to keep Norwich Group intact. Computer Weekly 1.

Daily, C. M., \& Dalton, D. R. (1992). The relationship between governance structure and corporate performance in entrepreneurial firms Journal of Business Venturing. 375-386.

Daily, C. M., \& Dalton, D. R. (1997). CEO and board chair roles held jointly or separately: Much ado about nothing? Academy of Management Executive, 11 (3), 11-20.

Daily, C. M., \& Johnson, J. L. (1997). Sources of CEO power and firm financial performance: A longitudinal assessment. Journal of Management. 23, 97-117.

Dalton, D. R., Daily, C. M., Ellstrand, A. E., \& Johnson J. L. (1998). Meta-analytic reviews of board composition, leadership structure, and financial performance. Strategic Management Journal, 19, 269-290.

Davis, G. F., \& Thompson, T. (1994). A social movement perspective on corporate control. Administrative Science Quarterly, 39, 141-173.

Dobrzynski, J. H. (1997a, February 11). A top-ten few companies care to be on. New York Times, $\mathrm{C} 3: 3$.

Dobrzynski, J. H. (1997b, March 7). Big investors train their fire on nonperforming directors. New York Times, C6: 1.

Fama, E. F. (1976). Foundations of Finance. New York: Basic Books.

Fama, E. F., \& Jensen, M. C. (1983). Separation of ownership and control. Journal of Law and Economics, 26, 327-349.

Freeman, S. J., \& Cameron, K. (1993). Organizational downsizing: A convergence and reorientation framework. Organization Science, $4,10 \mathrm{~m} 29$.

Gordon, J. N. (1994). Institutions as relations investors: A new look at cumulative voting. Columbia Law Review, 94, 124-192.

Graves, S. B. (1988). Institutional ownership and corporate R\&D in the computer industry. Academy of Management Journal, 31, 417-428.

Harrison, J. R. (1987). The strategic use of corporate board committees. California Management Review, 30 (1), 109-125. 
Heenan, D. A. (1993, October). Reformation redux. Chief Executive (U.S.), 50-53.

Hermalin, B., \& Weisbach, M. S. (1988). The determinants of board composition. Rand Journal of Economics, $19,589-606$.

Horton, T. R. (1991). Human resources in the boardroom. Management Review. 80 (3), 1-3.

Hoskisson, R. E., Johnson, R. A., \& Moesel, D. D. (1994). Corporate divestiture intensity in restructuring firms: Effects of governance, strategy, and performance. Academy of Management Journal, 37, 1207-1251.

Jensen, M. C., \& Meckling, W. H. (1976). Theory of the firm: Managerial behavior, agency costs and ownership structure. Journal of Financial Economics. 3, 305-360.

Johnson, R. A., Hoskisson, R. E., \& Hitt, M. A. (1993). Board of director involvement in restructuring: The effects of board versus management controls and characteristics. Strategic Management Journal, 14, 33-50.

Judge, W. Q., \& Zeithaml, C. P. (1992). Institutional and strategic choice perspectives on board involvement in the strategic decision process. Academy of Management Journal. 35, 766-794.

Kesner, I. F., \& Johnson, R. B. (1990). An investigation of the relationship between board composition and stockholder suits. Strategic Management Journal. 11, 327-345.

Kosnik, R. (1987). Greenmail: A study of board performance in corporate governance. Administrative Science Quarterly, 32, 163-185.

Lear, R. W. (1997, August). Twenty years of corporate governance. Chief Executive, 16-19.

Lear, R. W., \& Yavitz, B. (1997, October). Hanging by a thread. Chief Executive, 46-51.

Lee, P. W. (1997). A comparative analysis of layoff announcements and stock price reactions in the United States and Japan. Strategic Management Journal, 18, 879-894.

Lorsch, J. W. (1989). Pawns or potentates: The reality of America's corporate boards. Boston: Harvard Business School Press.

Lorsch, J. W. (1996 July-August). The board as a change agent. Corporate Board, 1-6.

Lubatkin, M. H., \& Shrieves, R. E. (1986). Towards reconciliation of market performance measures to strategic management research. Academy of Management Review. 11 , $497-512$.

Lubatkin, M. H., Chung, K. H., Rogers, R. C., \& Owers, J. E. (1989). Stockholder reactions to CEO changes in large corporations. Academy of Management Journal, 32, 47-68. 
Mallette, P., \& Fowler, K. L. (1992). Effects of board composition and stock ownership on the adoption of "poison pills." Academy of Management Journal, 35, 1010-1035.

McLaughlin, D. J. (1994). The director's stake in the enterprise. Directors \& Boards. 18 (2), 53-60.

McWilliams, A., \& Siegel, D. (1997). Event studies in management research: Theoretical and empirical issues. Academy of Management Journal, 40, 626-657.

McWilliams, V. B. (1990). Managerial share ownership and the stock price effects of antitakeover amendment proposals. Journal of Finance, 45, 1627-1640.

Mizruchi, M. (1983). Who controls whom? An examination of the relations between management and the board of directors in large American corporations. Academy of Management Review, 8, 426-435.

Morrissey, J. (1994). Quarterdeck CEO resigns over drastic cost-cutting. PC Week, 11 (34), 109-110.

Nelson, C. A. (1995, May-June). The challenge of restructuring. Corporate Board, 20-23.

Pfeffer, J. (1981). Management as symbolic action: The creation and maintenance of organizational paradigms. In L.L. Cummings and B. M. Staw (Eds.), Research in Organizational Behavior (Vol. 3). Greenwich, CT: JAI Press, 1-52.

Pound, J. (1992). Beyond takeovers: Politics comes to corporate control. Harvard Business Review, 70, 83-93.

Queenan, J. (1996, November). Getting (virtually) real. Chief Executive, 70.

Rechner, P. L., \& Dalton, D. R. (1991). CEO duality and organizational performance: A longitudinal analysis. Strategic Management Journal. 12, 155-160.

Rediker, K. J., \& Seth, A. (1995). Boards of directors and substitution effects of alternative governance mechanisms. Strategic Management Journal, 16, 85-99.

Corporate responsibility and the board. (1996, September-October). Corporate Board, 1-3.

Rosenstein, S., \& Wyatt, J. (1990). Outside directors, board independence, and shareholder wealth. Journal of Financial Economics. 26, 175-192.

Schellhardt, T. D. (1991, March 20). More directors are recruited from outside. Wall Street Journal, B1.

Stulz, R. (1988). Managerial control of voting rights: Financing policies and the market for corporate control. Journal of Financial Economics, 20, 25-54. 
Sundaramurthy, C. (1996). Corporate governance within the context of antitakeover provisions. Strategic Management Journal. 15, 377-394.

Sundaramurthy, C., \& Rechner, P. L. (1997). Conflicting shareholder interest: An empirical analysis of fair price provisions. Business and Society. 36, 73-88.

Sundaramurthy, C., Mahoney, J. M., \& Mahoney, J. T. (1997). Board structure, antitakeover provisions, and stockholder wealth. Strategic Management Journal, 18, 231 -245.

Weisbach, M. S. (1988). Outside directors and CEO turnover. Journal of Financial Eco: nomics, $20,431-460$.

Westphal, J. D., \& Zajac, E. (1995). Who shall govern? CEO/board power, demographic similarity, and new director selection. Administrative Science Ouarterly. 40, 60-83.

Witte, D. L. (1997, May-June). The board as a strategy-setting force. Corporate Board, 10-15.

Worrell, D. L., Davidson, W. N., \& Sharma, V. M. (1991). Layoff announcements and stockholder wealth. Academy of Management Journal, 34, 662-678.

Zahra, S. A., \& Pearce, J. A. (1989). Boards of directors and corporate financial performance: A review and integrative model. Journal of Management, 15, 291-334.

Zald, M. (1969). The power and function of boards of directors: A theoretical synthesis. American Joumal of Sociology, 73, 261-272.

\section{Endnotes}

Recent studies show that both positive and negative abnormal stock market returns occur in response to layoff announcements (Lee, 1997; Worrell, Davidson, \& Sharma, 1991). 
Appendix

Sample Firms and Layoff Announcement Dates

\begin{tabular}{|c|c|}
\hline Company Name & Announcement Date \\
\hline ACUSON CORP & $06 / 03 / 93$ \\
\hline ADVANCED MICRO DEVICES INC & $11 / 16 / 90$ \\
\hline AETNA LIFE \& CASUALTY CO & $06 / 30 / 92$ \\
\hline ALEX BROWN INC & $11 / 28 / 90$ \\
\hline AMAX CORP & $06 / 21 / 90$ \\
\hline AMDAHL CORP & $10 / 13 / 92$ \\
\hline AMDAHL CORP & $04 / 23 / 93$ \\
\hline AMERICAN EXPRESS CO & $03 / 01 / 90$ \\
\hline AMERICAN TELEPHONE \& TELEG CO & $03 / 04 / 92$ \\
\hline APPLE COMPUTER INC & $01 / 16 / 90$ \\
\hline APPLIED MAGNETICS CORP & $07 / 19 / 93$ \\
\hline APPLIED MATERIALS INC & $11 / 16 / 90$ \\
\hline ATLANTIC RICHFIELD CO & $08 / 26 / 91$ \\
\hline AVON PRODUCTS INC & $04 / 17 / 92$ \\
\hline BAXTER INTER NATIONAL INC & $04 / 05 / 90$ \\
\hline BAXTER INTERNATIONAL INC & $11 / 17 / 93$ \\
\hline BECKMAN INSTRUMENTS INC NEW & $10 / 19 / 93$ \\
\hline BELL ATLANTIC CORP & $09 / 15 / 89$ \\
\hline BELL ATLANTIC CORP & $07 / 10 / 92$ \\
\hline BELLSOUTH CORP & $11 / 09 / 92$ \\
\hline BLOUNT INC & $01 / 17 / 89$ \\
\hline BORDEN CO & $09 / 29 / 89$ \\
\hline BORDEN CO & $01 / 13 / 92$ \\
\hline BORLAND INTERNATIONAL INC & $12 / 10 / 92$ \\
\hline BRUNSWICK CORP & $07 / 20 / 89$ \\
\hline BRUNSWICK CORP & $07 / 09 / 90$ \\
\hline BURR BROWN CORP & $03 / 19 / 92$ \\
\hline BUSINESSLAND INC & $01 / 11 / 90$ \\
\hline C R S S INC & $08 / 20 / 92$ \\
\hline CAROLINA POWER \& LIGHT CO & $08 / 29 / 89$ \\
\hline CENTERIOR ENERGY CORP & $03 / 24 / 93$ \\
\hline CINCINNATI \& SUBN BELL TEL & $12 / 09 / 92$ \\
\hline CINCINNATI GAS \& ELEC CO & $07 / 23 / 92$ \\
\hline COMMONWEALTH EDISON CO & $01 / 23 / 89$ \\
\hline COMMONWEALTH EDISON CO & $07 / 23 / 92$ \\
\hline COMPAQ COMPUTER CORP & $10 / 08 / 92$ \\
\hline CONNER PERIPHER ALS INC & $10 / 22 / 93$ \\
\hline CRAY RESEARCH INC & $10 / 03 / 89$ \\
\hline CYPRUS MINERALS CO & $03 / 12 / 92$ \\
\hline CYPRUS MINERALS CO & $07 / 08 / 93$ \\
\hline CYTOGEN CORP & $09 / 20 / 93$ \\
\hline D S C COMMUNICATIONS CORP & $08 / 05 / 91$ \\
\hline DATA GENERAL CORP & $10 / 11 / 89$ \\
\hline DATA GENERAL CORP & $04 / 02 / 92$ \\
\hline
\end{tabular}


DAYTON HUDSON CORP

$06 / 26 / 90$

DAYTON HUDSON CORP

$03 / 10 / 92$

DENNISON MANUFACTURING CO

$12 / 15 / 89$

DIGITAL EQUIPMENT CORP

$04 / 27 / 92$

DUN \& BRADSTREET INC

$12 / 01 / 92$

DUN \& BRADSTREET INC

$11 / 01 / 93$

FIRST FIDELITY BANCORP

03/06/90

FLEET NORSTAR FINANCIAL GRP INC

$12 / 07 / 90$

FLORIDA POWER \& LIGHT

$10 / 25 / 93$

GENERAL ELECTRIC CO

$01 / 25 / 90$

GENERAL ELECTRIC CO

$02 / 26 / 92$

GERBER PRODUCTS CO

$01 / 14 / 92$

GOODYEAR TIRE \& RUBBER CO

$03 / 14 / 91$

HARLEY DAVIDSON INC

$09 / 24 / 90$

HARRIS CORP

$04 / 06 / 92$

HASBRO INDUSTRIES INC

$05 / 30 / 91$

$04 / 04 / 89$

ILLINOVA CORP HOLDING CO

$04 / 27 / 90$

INTEL CORP

$12 / 05 / 89$

$12 / 07 / 90$

INTERNATIONAL BUSINESS MACHS COR

$03 / 28 / 91$

INTERNATIONAL BUSINESS MACHS COR

$07 / 29 / 92$

INTERNATIONAL BUSINESS MACHS COR

$02 / 11 / 93$

INTERNATIONAL BUSINESS MACHS COR

$02 / 17 / 93$

IOMEGA CORP

08/30/91

KEY TRONICS CORP

$08 / 06 / 90$

LOTUS DEVELOPMENT CORP

$11 / 07 / 89$

LOUISVILLE GAS \& ELEC CO

$04 / 11 / 91$

$M$ A I SYSTEMS CORP

$06 / 27 / 91$

MACDERMID INC

$10 / 11 / 93$

MAGMA COPPER CO NEW

$12 / 06 / 89$

MCGRAW HILL PUBLISHING INC

$07 / 03 / 92$

MEAD CORP

$03 / 24 / 93$

MERCK \& CO INC

$05 / 01 / 92$

MIDLANTIC CORP

$03 / 19 / 92$

MOBIL OIL CORP

$07 / 01 / 91$

MONSANTO CHEMICAL CO

$11 / 23 / 92$

MONSANTO CHEMICAL CO

$01 / 17 / 89$

NATIONAL SEMICONDUCTOR CORP

$09 / 20 / 90$

NIAGARA MOHAWK POWER CORP

02/03/93

NIAGARA MOHAWK POWER CORP

$09 / 17 / 91$

NYNEX CORP

$12 / 02 / 93$

NYNEX CORP

$02 / 14 / 91$

OCCIDENTAL PETROLEUM CORP

$10 / 15 / 91$

ORYX ENERGY CO

$09 / 11 / 92$

PENNEY J C INC

$02 / 04 / 92$

PEPSICO INC

$10 / 20 / 93$

PFIZER CHAS \& CO INC

$05 / 06 / 92$

PHILIP MORRIS \& CO LTD

$11 / 26 / 93$

PHILIP MORRIS \& CO LTD 
PHILLIPS PETROLEUM CO

$02 / 19 / 92$

PITNEY BOWES INC

$12 / 13 / 89$

PORTLAND GENERAL ELECTRIC CO

$08 / 12 / 91$

RAYTHEON MANUFACTURING CO

$11 / 01 / 93$

SCOTT PAPER CO

$01 / 24 / 92$

SEARS ROEBUCK \& CO

$09 / 17 / 90$

SEARS ROEBUCK \& CO

$01 / 26 / 93$

SEQUENT COMPUTER SYSTEMS INC

$07 / 03 / 91$

SHAWMUT NATIONAL CORP

$01 / 24 / 91$

TAMBRANDS INC

$12 / 14 / 89$

TEKTRONIX INC

$05 / 30 / 90$

TENNECO INC

$10 / 23 / 91$

TENNECO INC

$12 / 05 / 91$

TEXAS INSTRUMENTS INC

$11 / 21 / 89$

TEXAS INSTRUMENTS INC

$07 / 19 / 91$

TEXAS INSTRUMENTS INC

$02 / 02 / 93$

TEXAS UTILITIES CO

$06 / 02 / 92$

TRAVELERS CORP

$01 / 25 / 89$

TRINOVA CORP

$10 / 19 / 89$

U S F \& G CORP

$01 / 17 / 91$

U S F \& G CORP

$04 / 06 / 91$

UNION CARBIDE \& CARBON CORP

$09 / 26 / 91$

UNISYS CORP

$02 / 21 / 89$

UNITED STATES SHOE CORP

$01 / 29 / 91$

UNITED STATES SHOE CORP

$01 / 29 / 92$

UNITED TECHNOLOGIES CORP

$08 / 03 / 90$

UNOCAL CORP

$04 / 28 / 92$

VARIAN ASSOC

$05 / 15 / 90$

$10 / 22 / 91$

WAL MART STORES INC

$04 / 17 / 89$

$11 / 03 / 89$

$04 / 27 / 90$

$01 / 17 / 91$

$07 / 01 / 91$

$11 / 24 / 93$

$02 / 01 / 89$

$12 / 12 / 91$

$12 / 09 / 93$

XEROX CORP

Richard W. Pouder is Assistant Professor of Management at Clemson University. He received his $\mathrm{Ph} . \mathrm{D}$. at the University of Connecticut. His research applies different conceptual perspectives to areas in strategic management such as technology, innovation, and restructuring.

R. Stephen Cantrell is Professor of Management and Economics at Clemson University. He received his Ph.D. in Economics and Statistics from North Carolina State University. His research interests include applied statistics, econometric aspects of business management, applied financial economics and strategic management issues in capital markets. 